\title{
Not Lost in Translation: Emerging Clinical Importance of the G Protein-Coupled Estrogen Receptor GPER
}

\author{
Matthias Barton, M.D. \\ Molecular Internal Medicine, University of Zurich, Switzerland
}

Short title:

GPER and translational clinical medicine

Abstract word count:

181

Word count:

3297

Number of references: 188

Figure:

Address for correspondence:

Matthias Barton, M.D.

University of Zurich

Molecular Internal Medicine

Y44 G22

Winterthurer Strasse 190

$\mathrm{CH}-8057$ Zürich

Switzerland

Phone: +41-77-439 5554

Email: barton@access.uzh.ch

This article is based in part on a plenary lecture presented at the $9^{\text {th }}$ International Meeting on the Rapid Responses to Steroid Hormones (RRSH 2015) held June 7-10, 2015 at National Yang Ming University, Taipei, Republic of Taiwan. 


\section{Summary}

It has been 20 years that the G protein-coupled estrogen receptor (GPER) was cloned as the orphan receptor GPR30 from multiple cellular sources, including vascular endothelial cells. Here, I will provide an overview on the historic development of rapid vascular estrogen signaling and review the recent advances in the understanding of the mechanisms underlying GPER function, its role in physiology and disease, some of the currently available GPER-targeting drugs approved for clinical use such as SERMs (selective estrogen receptor modulators) and SERDs (selective estrogen receptor downregulators). Many of currently used drugs such as tamoxifen, raloxifene, or faslodex ${ }^{\mathrm{TM}} /$ fulvestrant were discovered targeting GPER many years after they had been introduced to the clinics for entirely different purposes. This has important implications for the clinical use of these drugs and their modes of action, which I have termed 'reverse translational medicine'. Similarly, environmental pollutants known as 'endocrine disruptors' have been found to bind to GPER. This article will discuss recent evidence in these areas and also opportunities in translational clinical medicine and GPER research, including medical genetics, personalized medicine, prevention, and its theranostic use.

\footnotetext{
Abbreviations used

ER, estrogen receptor; GPER, G protein-coupled estrogen receptor; GPR30, G protein-coupled receptor 30; SERD, selective estrogen receptor downregulator; SERM, selective estrogen receptor modulator; DDT, dichlorodiphenyltrichloroethane
}

\section{Key words}

Estrogen biology; faslodex ${ }^{\mathrm{TM}}$, fulvestrant; clinical medicine; GPER-1; GPR30, tamoxifen, ICI 182,780; theranostics; cancer, atherosclerosis; coronary artery disease; multiple sclerosis; inflammation; autoimmune disease; patients; niacin; dyslipidemia; blood pressure; hypertension 
Contents

1. Clinical importance of estrogen signaling ................................... 4

2. Estrogen receptors: cellular mediators and therapeutic targets...............4

3. A G protein-coupled receptor that mediates estrogen action.................5

4. Drugs targeting GPER: Opportunities for 'reverse translational medicine'....7

5. Targeting GPER in cardiovascular disease, obesity, and diabetes.............8

6. Targeting GPER in immune disorders, infectious diseases, and cancer .....10

7. Endocrine disruptors and xenoestrogens as activators of GPER .............11

8. Summary and Conclusion..................................................... 12

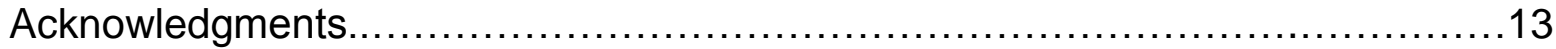

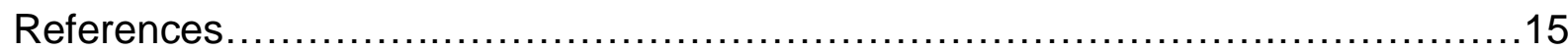




\section{Clinical importance of estrogen signaling}

Estrogens have been known only for about 80 years after German biochemist Adolf Butenandt (1903-1995) while at the University of Danzig (today Gdansk, Poland) and still in his twenties identified estrogen and other female sex hormones [1, 2] in collaboration with Schering AG, Berlin, isolating a mere $15 \mathrm{mg}$ of crystallized estrogen from 25'000 liters of urine. Butenandt's discovery was awarded the 1939 Nobel Prize in Chemistry, which he shared with the Croatian biochemist Leopold Ružička (1887-1976) who had succeeded in isolating testosterone in Zürich [3, 4]. Today, we know that in premenopausal women, endogenous estrogen production is mainly derived from the ovaries [5-7]. However in males and females estrogen is also produced in the arterial wall (from the aromatase-mediated conversion of testosterone [8, 9]) as well as other tissues, including adipose [10]. Estrogens are regulators of cell proliferation, bone growth, mammary gland proliferation, uterine growth, vascular tone, blood pressure, myocardial contractility, sympathetic activation, glucose metabolism, inflammation, adipogenesis and lipid metabolism [7, 9, 11-13], and consequently, atherogenesis [13]. In women, aberrant estrogen signaling or decreases/impairment of estrogen function (clinically well evident in patients diagnosed with polycystic ovary syndrome (PCOS) who are prone to develop arterial hypertension, diabetes, and obesity [14, 15]), promotes the development of disease such as cancer, atherosclerotic vascular disease, osteoporosis, hypertension and diabetes $[7,16]$. Though estrogens are known as prototypical "female sex hormones", they also play a role on male physiology $[6,7,17]$.

Given their involvement in disease processes, the understanding of how estrogens mediate cellular signaling, the function of estrogen receptors and their tissue specificity, and their agonism and antagonism has become increasingly important not only for estrogen-dependent diseases but particularly for therapeutic approaches targeting estrogen receptors. Estrogen-based therapies (utilizing anti-estrogens/SERMs or aromatase inhibitors) have become the major neoadjuvant therapeutic approach used for the treatment of breast cancer $[18,19]$.

\section{Estrogen receptors: cellular mediators and therapeutic targets}


The so-called "classical" estrogen receptors, $\operatorname{ER} \alpha$ and $\operatorname{ER} \beta[5,20,21]$, were cloned in 1985 [22-26] and 1996, respectively [26, 27], and nuclear as well as membrane-bound subpopulations of both receptors have been identified that are derived from the same transcript as the nuclear receptors [28, 29]. Today, particularly in clinical medicine, estrogens are still mainly known for mediating their cellular effects through "genomic" signaling regulating gene transcription, which involves the formation of receptor homo- or heterodimers, and binding to estrogen response elements (ERE) in the promoter and regulatory regions of target genes [20,30]. Nuclear ERs (even in the absence of ligand binding or direct binding to DNA) also interact with other classes of transcription factors and DNA modifying proteins through complex protein-protein interactions, thus further modifying cellular responses and functions [31].

By contrast, rapid, i.e. "non-genomic" vascular effects mediated by estrogen noted already at the beginning of the Second World War when in November 1939 Reynolds and Foster published rapid peripheral vasodilator effects of estrogen in healthy men that occurred within 3 to 15 minutes after infusion [32]. Half a century ago at the University of California Los Angeles cell biologist Clara M. Szego (1916 - ) observed in cell experiments that $17 \beta$-estradiol rapidly stimulates cAMP in uterine tissue within seconds after application [33-35], and it has been 40 years since Venter and Buonassisi [36] and Pietras and Szego [37] detected binding sites for estrogen on human endothelial cell and endometrial cell membranes, respectively; these experiments were subsequently confirmed in plasma membrane fractions of normal and tumor mammary human tissues [38]. The role of rapid estrogen signaling, however, has become increasingly appreciated only in the past two decades, and knowledge about the contribution of the receptors mediating rapid estrogen action to physiology and disease has only begun to evolve.

\section{A G protein-coupled receptor that mediates estrogen action}

In the early 1990s, I came across the early studies by Szego and coworkers [33$35,37]$ and set up similar experiments to study acute effects of $17 \beta$-estradiol on cAMP production in human coronary arteries [39, 40]. Following exposure to $17 \beta$-estradiol rapid increases of vascular cyclic AMP content (and also cyclic GMP content) could be 
observed within 30 minutes of application [39]. Within the same time frame a rapid and potent vasodilation of precontracted coronary artery rings in response to $17 \beta$-estradiol occurred, in both intact arteries from women and men [40, 41]. Both observations could not be explained by genomic mechanisms [39]. At that time no membrane receptor mediating rapid responses to estrogen was known [41]. In the following year, Benita Katzenellenbogen and associates confirmed these findings also demonstrating rapid increases in cyclic AMP content following exposure 17 $\beta$-estradiol within 30 minutes utilizing intact uterine tissue that was associated with activation of adenyl cyclase [42].

Shortly after these studies demonstrating rapid increases in cellular cAMP in response to $17 \beta$-estradiol had been published, a 7-transmembrane spanning G proteincoupled receptor was identified at Lund University in Sweden in 1996 [43]. Since at the time no known ligand existed this receptor was received the orphan receptor designation GPR30 [10]. The receptor was subsequently cloned from multiple other cell types, including inflammatory white blood cells [43, 44], breast cancer cells [45], endothelial cells [46]. The receptor was also identified following a database mining [47], degenerate oligonucleotide screening of genomic DNA [48], and as its rat homologue, GPR41 [49-51]. High expression of GPR30 was detected in vasculature, heart, renal tubules, lung, placenta, and the reproductive system, among others tissues and organs [10].

GPR30 was 'de-orphanized' as an estrogen receptor in 2000 in seminal studies by Filardo and associates, who demonstrated that abundance of GPER was required for the rapid estrogen-mediated ERK1/2 activation [52] and increasing cyclic AMP content [53]. At the same time, Levin and coworkers reported membrane subpopulations of ER $\alpha$ and ER $\beta$ [29] subsequently showing that they function as receptor dimers [54] while Nadal et al. reported rapid actions of estrogen and xenoestrogens that were mediated through a then unknown membrane receptor unrelated to ER $\alpha$ and ER $\beta$ [55]. Prossitz et al. and Thomas, Filardo and coworkers subsequently reported that GPR30 mediates rapid effects of estrogen [56, 57].

In 2007, GPR30 received the official new designation as « G protein-coupled estrogen receptor-1» (GPER-1) from the International Union of Basic and Clinical Pharmacology (IUPHAR) [58, 59]. The data currently available provide evidence that 
GPER not only plays a role in physiology of the reproductive system, vasculature, kidney, brain, in obesity and endocrine metabolism, but that it is also involved in estrogen-dependent diseases including cancers of the reproductive system, male fertility [60], obesity, osteoporosis, arterial hypertension, atherosclerosis, and autoimmune diseases including multiple sclerosis, as well as aging (reviewed in [10, 61, 62]). It is important to remember that GPER, like most other GPCRs, not only mediates "non-genomic" rapid effects, but also exerts tonic (constitutive/basal) activity that contributes to cell function and growth, as demonstrated by numerous studies in GPERdeficient mice [63-70]. A recent study found that GPER is responsible for the abnormal estrogen-dependent vasoconstriction and elevated blood pressure in female mice deficient in ephrin B3, and that these effects can be abrogated by ovariectomy [71], suggesting cross-talk between estrogen-dependent GPER function and ephrin pathways.

\section{Drugs targeting GPER: Opportunities for 'reverse translational medicine'}

It is noteworthy that selective estrogen receptor modulators, now known to activate GPER[10, 59, 61], were not initially intended for their current use. In fact, tamoxifen (ICl 46,474) was developed as a contraceptive pill but failed [72]. Tamoxifen had been patented by as a hypocholesterolemia drug in the early 1960's and related compounds also affected cholesterol metabolism and biosynthesis [72]. Of note, more than 50 years later activation of the tamoxifen target GPER has been implicated in beneficial effects on cholesterol metabolism $[62,68,73]$. The number molecules targeting GPER with agonistic or antagonistic activity continues to grow and those currently known been recently summarized [10,62]. Among others, these substances include natural steroid hormones such $17 \beta$-estradiol (a non-selective ER agonist), its metabolites (2-hydroxy-estradiol [74], a catechol estrogen [75]), selective estrogen receptor modulators (SERMs, including tamoxifen, raloxifene) [59], selective estrogen receptor downregulators (SERDs, ICI 182, 780, faslodex ${ }^{T M}$ /fulvestrant [59]), vitamin $\mathrm{B}_{3} /$ niacin [76], phytoestrogens such as genistein [59], daidzein [59], the daidzien metabolite equol [77], resveratrol, green tea catechins [78], synthetic compounds non-selectively (PPT) $[59,79]$ or selectively targeting GPER (G-1, G15, G36 [59]), as well as endocrine 
disruptors/xenoestrogens such as bisphenol A and DDT [10,59] (see Figure 1 for an overview of GPER activators and inhibitors).

GPER may not only have direct effects upon ligand activation, but its function critically involves receptor interactions, i.e. cross-talk with nuclear steroid receptors, including ER $\alpha$ [80], ER $\beta$ [81], mineralocorticoid receptor (MR), vitamin D receptor (VDR), and the glucocorticoid receptor (GR) (reviewed in [17, 61]). Moreover, the recent availability of drugs that selectively activate ER $\beta$ [82-84] or GPER [59] and given that substances such as propyl pyrazole triol (PPT, commonly used as ER $\alpha$-selective agonist) can also activate $\operatorname{ER} \beta[85]$ and GPER $[59,79]$, have added to the complexity of estrogen action and understanding the roles and interplay between individual estrogen receptors [11, 86]. Finally, under certain pathological conditions activation of individual estrogen receptors may exert comparable beneficial effects [12, 87]. In contrast to data indicating functional crosstalk between MR and GPER $[17,88]$, there no evidence to support the notion that GPER functions as a receptor for aldosterone [88, 89] as has been proposed by some $[90,91]$ since no binding of aldosterone to GPER could be detected [92, 93].

Over the past decade, numerous molecules were identified to either activate or inhibit GPER [10,59,61]. Several of these drugs were discovered to target GPER many years after they had been already introduced to the clinics for entirely different purposes, e.g. as neoadjuvant cancer therapeutics [10,61]. These drugs particularly include SERMs such as tamoxifen, raloxifene, and SERDs like falsodex ${ }^{\mathrm{TM}} /$ fulvestrant $^{2}$ (ICI 182, 780) [17]. These newly discovered modes of action of clinically approved drugs require us to rethink and extend our therapeutic rationale that we apply when administering these drugs to patients [10]. In fact, we need to go 'from bench to bedside and back' (as proposed 20 years ago by Marie Gerhard and Peter Ganz [94]) to understand how estrogen receptor-targeting drugs work and may benefit patients, an approach which I have termed 'reverse translational medicine'. In the following two paragraphs, I will give some examples and discuss how this may impact and change our understanding of clinical treatments of disease.

\section{Targeting GPER in cardiovascular disease, obesity, and diabetes}


The protective effects of endogenous estrogen on cardiovascular disease, arterial hypertension, obesity, dyslipidemia, and diabetes in women become evident after menopause [7, 9]. These effects are only partly mediated by the "classical" ER $\alpha$ $[95,96]$, and also involve GPER-dependent mechanism [62, 68]. Notably, many of the salutary effects of estrogen are absent in GPER-deficient mice $[65,66,97])$ and can be mimicked by GPER-activating compounds, which exert beneficial effects on arterial hypertension [9, 98] and the associated hypertensive renal injury [99], insulin resistance and diabetes [12, 70, 87], dyslipidemia [68, 73], and also reduces adipogenesis [97, $100]$ and thus obesity - which conversely is increased in animals lacking GPER [65, 66, 97]. The latter suggests an important role of GPER as a receptor with "constitutive", i.e. ligand-independent basal activity.

Many compounds currently in clinical use exhibit activity towards GPER; in view of the recent discovery that SERMs and SERDs - which not only block the "classical" estrogen receptors $E R \alpha$ and $E R \beta$ (which would not explain the beneficial effects) - but like the soy phytoestrogens genistein [59] and daidzein [59], green tea catechins [78] or niacin [76] also exhibiting agonistic activity towards GPER, the clinical data currently available needs to be reassessed. As phytoestrogens also improve lipid and glucose metabolism [101-105] as well as neointima formation after balloon angioplasty [106], the above drugs and substances are considered for primary or secondary prevention of cardiovascular and metabolic diseases [13,62].

The GPER gene maps to chromosome 7p22.3, a region linked to arterial hypertension in humans $[65,107]$. Moreover, recent clinical studies have found an association between Gper gene function and arterial blood pressure [108]. In addition to numerous preclinical investigations [109-115], clinical studies have shown that SERMs or SERDs improve vasodilation [116-118] and arterial stiffness [119], lower blood pressure [120, 121], improve the lipid and glucose profile [122-126], reduce circulating fibrinogen levels [127], and educe cardiovascular events in postmenopausal women $[128,129]$ - all effects that are compatible with GPER activation while blocking ER $\alpha$ and/or ER $\beta$ would be expected to yield the opposite effects [9]. Finally, a common side effect in breast cancer patients receiving the SERD fulvestrant frequently report 
hypotension as an unwanted side effect [121], which so far could not been explained mechanistically. We [109] and others [130] have demonstrated that the GPER agonist fulvestrant causes rapid vasodilation which might explain the frequent occurrence of hypotension observed in patients receiving this drug.

Niacin (vitamin $B_{3}$ ) has used for more than half a century as an effective treatment for dyslipidemia in patients at risk for or diagnosed with coronary, cerebrovascular, or peripheral artery disease [131]. Its mode of action has been recently been attributed to two $G$ protein-coupled receptors of high and low affinity, respectively, GPR109A (MH74A) and GPR109B (HM74) [131-133]. Recent evidence however suggests that niacin is also capable of activating GPER [76] which would be compatible with the lipid-lowering effect seen in patients treated with SERMs and SERDs [122, 123]. A role for GPER as a modulator of lipid metabolism is also supported by clinical studies demonstrating influences of its gene function on the lipid profile [73]. Of note, selective GPER activation has been shown to inhibit angiogenesis [61, 62], which may confer additional therapeutic benefits in cancer patients. A recent study found that nicotinamide, the amide form of niacin, inhibits vasculogenic mimicry in vitro [134], a pathway that has implicated in the pathogenesis of highly aggressive melanoma. An inhibitory effect on vasculogenesis would be compatible with GPER activation [10]. Also, a dramatic beneficial effect of niacin on UV-induced DNA damage in patients with autosomal recessive xeroderma pigementosum (Cockayne syndrome) has been recently reported, which possibly involves GPER activation.

Taken together, clinically used SERMS, dyslipidemia therapeutics as well as phytoestrogens show therapeutic benefits on cardiovascular and metabolic profiles in patients that are consistent with a GPER-activating function rather than with blocking the "classical" estrogen receptors. Further research is required to delineate of whether and how much these effects involve GPER.

\section{Targeting GPER in immune disorders, infectious diseases, and cancer}

Estrogens play an important role in modulating immune responses, thereby contributing to autoimmune diseases, infection, and diseases with a strong inflammatory component such as vascular and renal disease, obesity, and diabetes [10, 61]. GPER 
was cloned from white blood cells [43], among other cellular sources, and its initial suggested role was that of a cytokine receptor [10]. It is not surprising that an important immunomodulatory role of GPER could be demonstrated [10].

GPER is expressed and functional in human monocytes [135] , macrophages [135], eosinophiles [136], lymphocytes [43, 137-139], and the fish equivalent of human neutrophiles [140]. There is now preclinical evidence that activation of GPER reduces inflammation in endothelial cells [141, 142], in atherosclerotic plaque [68] and myocardium of failing hearts [143]. Moreover, GPER is involved in protective, estrogenmediated effects of autoimmune diseases in models of multiple sclerosis [144-146], as well as chronic infections caused by hepatitis C virus (HCV) [147]. Moreover, roles of GPER in different forms of cancer of the reproductive and non-reproductive cancers have been demonstrated (reviewed in [10]). Recent clinical studies suggest that SERMs may indeed provide therapeutic efficacy as adjuvant therapy in non-gynecological cancers such as metastatic prostate cancer [148] or as sensitizers of cytostatic drugs in patients with pancreatic cancer [149]. Moreover, the use of SERMs for the treatment of Candida albicans or Staphylococcus aureaus infections [150] or infections caused by Ebola virus [151] has been proposed.

As with the studies demonstrating beneficial effects of SERMs, SERDs, phytoestrogens, and niacin/vitamin $\mathrm{B}_{3}$ in cardiovascular and metabolic diseases, similar results using these compounds were obtained regard to immune-mediated diseases and cancer ([152, 153] and reviewed in [59]). Raloxifene has been shown to inhibit inflammatory activation and cell growth [154,155], as has been demonstrated for GPER-activating phytoestrogens [156-159] and niacin [160]. The profound antiinflammatory effects of these substances have also been observed clinical studies studying diseases with inflammatory activation [161-163]. As discussed above, currently it is unclear whether and to what extent the beneficial effects of these compounds can be ascribed to GPER. Future preclinical and clinical studies should be directed toward addressing this question.

\section{Endocrine disruptors and xenoestrogens as activators of GPER}


Xenoestrogens are synthetic or natural substances of high stability that exert toxicity by mimicking the effects of estrogens [164]. These stable chemicals are products of modern technology used in manufacturing consumer products including detergents, surfactants, resins, lubricants, plasticizers, fire retardants, and pesticides [59] and they accumulate in the environment, including in ground water, fruits and vegetables [165], and can even be found in bottled mineral water [166]. Because of their endocrine activity they have been designated 'endocrine disruptors", also known as 'environmental pollutants' [10]. Numerous synthetic compounds (e.g. pesticides and plastic precursors) that act as endocrine disruptors with metabolic and reproductive effects have been found to activate GPER (reviewed in [59]). These chemicals include atrazine, bisphenol A, nonylphenol, kepone, chlorinated hydrocarbons and their metabolites and degradation products such as $p, p-D D T, o, p-D D E$ and 2,2,5,- $P C B-4-O H$ (reviewed in $[10,59,61,62])$, as well as the mycotoxin zearalonone [167]. At this point it is not known to what degree endocrine disruptors mediate their deleterious effects in humans through GPER, and to which other mechanisms are involved. Research also concentrates on chemical classes such as alkyl phenols and esters of parahydroxybenzoic acid, phthalates, polybrominated diphenyl ethers, organophosphates, chlorinated hydrocarbons, and biphenyls [59]. Bisphenol A (BPA) is produced in great quantities globally, primarily for use in polycarbonate plastics and epoxy resins, with the safety of human exposures to BPA being subject of intensive scientific assessment and regulatory efforts [59, 168, 169]. Since endocrine disruptors have implicated in a number of health concerns, including embryonic and early life development [164, 170], progenitor cell function [171], female and male reproduction and development [164, 172], infertility, cancer [172], autoimmune diseases [164], obesity and metabolic disorders [173, 174], epigenetic programming in adolescents $[164,175]$, arterial hypertension [176], polycystic ovary syndrome (PCOS) [177-179] as well as deleterious effects of prenatal exposure to xenoestrogens [164, 180]. Given that many endocrine disruptors also activate GPER future clinical research should be directed to explore which of the known estrogen receptors mediates their deleterious effects, and/or whether other mechanisms also play a role. 


\section{Summary and Outlook}

As discussed, the obvious and potent beneficial effects of clinically used drugs such as SERMs, SERDs, and niacin (which can also be observed for certain phytoestrogens and green tea constituents [181]) cannot be explained by blocking the "classical" estrogen receptors and based on recent preclinical finding likely involve an activating effect on GPER. Applying "reverse translational medicine" we should rethink our therapeutic approaches when using these drugs which also suggest possible new therapeutic indications such as for the treatment of bleeding in hereditary heamorrhagic telangiectasia [182] and possibilities for future drug development. Medical genetics studies have found that genetic polymorphisms of GPER are associated with changes in cell function [183] or disease susceptibility for dyslipidemia [73], arterial hypertension [108], seminoma [184], gastric cancer [185], breast cancer [186], leiomyoma [187] and gynecomastia in adolescents [188] providing us with new opportunities for personalized medicine, theranostics, and thereby improving treatment and prevention. Continued clinical research is required to increase our understanding of estrogen receptors and the clinically approved drugs targeting them and how these drugs mediate therapeutic benefits and unwanted side effects in patients, which ultimately will improve patient safety and survival. 


\section{Acknowledgment}

Supported by the Swiss National Science Foundation grants Nr. 108256 and 122504 . The author is indebted to Matthias Meyer, M.D., for valuable discussion and suggestions on the manuscript.

\section{Role of the funding sources}

The funders had no involvement in the drafting, writing, or decision to submit the present article for publication. 


\section{References}

[1] Butenandt A. Über "Progynon" ein krystallisiertes weibliches Sexualhormon. Die Naturwissenschaften. 1929;17:879.

[2] Butenandt A. Über die chemische Untersuchung der Sexualhormone. Z Angew Chem. 1931;44:905-16.

[3] Ružička L, Wettstein A. Sexualhormone V. Künstliche Herstellung des männlichen Sexualhormons trans-Dehydro-androsteron und des Androsten-3,17-dions. Helv Chim Acta. 1935;18:986-4.

[4] Ružička L, Wettstein A. Sexualhormone VII. Synthetische Darstellung des Testishormons, Testosteron (Androsten-3-on17-ol). Helv Chim Acta. 1935;18:126475.

[5] Burns KA, Korach KS. Estrogen receptors and human disease: an update. Arch Toxicol. 2012;86:1491-504.

[6] Deroo BJ, Korach KS. Estrogen receptors and human disease. J Clin Invest. 2006;116:561-70.

[7] Meyer MR, Clegg DJ, Prossnitz ER, Barton M. Obesity, insulin resistance and diabetes: sex differences and role of oestrogen receptors. Acta Physiol (Oxf). 2011;203:25969.

[8] Nathan L, Shi W, Dinh H, Mukherjee TK, Wang X, Lusis AJ, et al. Testosterone inhibits early atherogenesis by conversion to estradiol: critical role of aromatase. Proc Natl Acad Sci U S A. 2001;98:3589-93.

[9] Meyer MR, Prossnitz ER, Barton M. The G protein-coupled estrogen receptor GPER/GPR30 as a regulator of cardiovascular function. Vascul Pharmacol. 2011;55:17-25.

[10] Prossnitz ER, Barton M. The G-protein-coupled estrogen receptor GPER in health and disease. Nat Rev Endocrinol. 2011;7:715-26.

[11] Turgeon JL, McDonnell DP, Martin KA, Wise PM. Hormone therapy: physiological complexity belies therapeutic simplicity. Science. 2004;304:1269-73.

[12] Tiano JP, Mauvais-Jarvis F. Importance of oestrogen receptors to preserve functional beta-cell mass in diabetes. Nat Rev Endocrinol. 2012;8:342-51.

[13] Barton M. Cholesterol and atherosclerosis: modulation by oestrogen. Curr Opin Lipidol. 2013;24:214-20. 
[14] Jayasena CN, Franks S. The management of patients with polycystic ovary syndrome. Nat Rev Endocrinol. 2014;10:624-36.

[15] Rachon D, Teede H. Ovarian function and obesity--interrelationship, impact on women's reproductive lifespan and treatment options. Mol Cell Endocrinol. 2010;316:172-9.

[16] Mauvais-Jarvis F, Clegg DJ, Hevener AL. The role of estrogens in control of energy balance and glucose homeostasis. Endocr Rev. 2013;34:309-38.

[17] Barton M. Position paper: the membrane estrogen receptor GPER - clues and questions. Steroids. 2012;77:935-42.

[18] Fan P, Maximov PY, Curpan RF, Abderrahman B, Jordan VC. The molecular, cellular and clinical consequences of targeting the estrogen receptor following estrogen deprivation therapy. Mol Cell Endocrinol. 2015;418 Pt 3:245-63.

[19] Jordan VC. Tamoxifen as the first targeted long-term adjuvant therapy for breast cancer. Endocr Relat Cancer. 2014;21:R235-46.

[20] Dahlman-Wright K, Cavailles V, Fuqua SA, Jordan VC, Katzenellenbogen JA, Korach KS, et al. International Union of Pharmacology. LXIV. Estrogen receptors. Pharmacol Rev. 2006;58:773-81.

[21] Hewitt SC, Winuthayanon W, Korach KS. What's new in estrogen receptor action in the female reproductive tract. J Mol Endocrinol. 2016;56:R55-R71.

[22] Green S, Walter P, Greene G, Krust A, Goffin C, Jensen E, et al. Cloning of the human oestrogen receptor cDNA. J Steroid Biochem. 1986;24:77-83.

[23] Green S, Walter P, Kumar V, Krust A, Bornert JM, Argos P, et al. Human oestrogen receptor cDNA: sequence, expression and homology to v-erb-A. Nature. 1986;320:134-9.

[24] Walter P, Green S, Greene G, Krust A, Bornert JM, Jeltsch JM, et al. Cloning of the human estrogen receptor cDNA. Proc Natl Acad Sci U S A. 1985;82:7889-93.

[25] Greene GL, Gilna P, Waterfield M, Baker A, Hort Y, Shine J. Sequence and expression of human estrogen receptor complementary DNA. Science. 1986;231:1150-4.

[26] Hewitt SC, Korach KS. Estrogen receptors: structure, mechanisms and function. Rev Endocr Metab Disord. 2002;3:193-200. 
[27] Kuiper GG, Enmark E, Pelto-Huikko M, Nilsson S, Gustafsson JA. Cloning of a novel receptor expressed in rat prostate and ovary. Proc Natl Acad Sci U S A. 1996;93:5925-30.

[28] Levin ER. Cellular functions of plasma membrane estrogen receptors. Steroids. 2002;67:471-5.

[29] Razandi M, Pedram A, Greene GL, Levin ER. Cell membrane and nuclear estrogen receptors (ERs) originate from a single transcript: studies of ERalpha and ERbeta expressed in Chinese hamster ovary cells. Mol Endocrinol. 1999;13:307-19.

[30] Gustafsson JA. Historical overview of nuclear receptors. J Steroid Biochem Mol Biol. 2016;157:3-6.

[31] Schultz-Norton JR, Ziegler YS, Nardulli AM. ERalpha-associated protein networks. Trends Endocrinol Metab. 2011;22:124-9.

[32] Reynolds SRM, Foster FI. Peripheral vascular action of estrogen in the human male. J Clin Invest. 1939;18:649-55.

[33] Szego CM, Davis JS. Adenosine 3',5'-monophosphate in rat uterus: acute elevation by estrogen. Proc Natl Acad Sci U S A. 1967;58:1711-8.

[34] Szego CM, Davis JS. Inhibition of estrogen-induced elevation of cyclic 3',5'-adenosine monophosphate in rat uterus. I. By beta-adrenergic receptor-blocking drugs. Mol Pharmacol. 1969;5:470-80.

[35] Pietras RJ, Szego CM. Endometrial cell calcium and oestrogen action. Nature. 1975;253:357-9.

[36] Buonassisi V, Venter JC. Hormone and neurotransmitter receptors in an established vascular endothelial cell line. Proc Natl Acad Sci U S A. 1976;73:1612-6.

[37] Pietras RJ, Szego CM. Specific binding sites for oestrogen at the outer surfaces of isolated endometrial cells. Nature. 1977;265:69-72.

[38] Zanker KS, Prokscha GW, Blumel G. Plasma membrane-integrated estrogen receptors in breast tissue: possible modulator molecular for intracellular hormone level. J Cancer Res Clin Oncol. 1981;100:135-48.

[39] Barton M. Akute Wirkungen von $17 \beta$-Oestradiol auf den Tonus menschlicher Arterien in vitro. Doctor of Medicine (D.M.) Dissertation, Hannover Medical School, Hannover, Germany (1994): 1-79. 1994. 
[40] Mügge A, Riedel M, Barton M, Kuhn M, Lichtlen PR. Estrogen dilates human coronary arteries in vitro by an increase in cyclic GMP and cyclic AMP smooth muscle content. Eur Heart J. 1993:16.

[41] Mügge A, Riedel M, Barton M, Kuhn M, Lichtlen PR. Endothelium independent relaxation of human coronary arteries by 17 beta-oestradiol in vitro. Cardiovasc Res. 1993;27:1939-42.

[42] Aronica SM, Kraus WL, Katzenellenbogen BS. Estrogen action via the cAMP signaling pathway: stimulation of adenylate cyclase and cAMP-regulated gene transcription. Proc Natl Acad Sci U S A. 1994;91:8517-21.

[43] Owman C, Blay P, Nilsson C, Lolait SJ. Cloning of human cDNA encoding a novel heptahelix receptor expressed in Burkitt's lymphoma and widely distributed in brain and peripheral tissues. Biochem Biophys Res Commun. 1996;228:285-92.

[44] Kvingedal AM, Smeland EB. A novel putative G-protein-coupled receptor expressed in lung, heart and lymphoid tissue. FEBS Lett. 1997;407:59-62.

[45] Carmeci C, Thompson DA, Ring HZ, Francke U, Weigel RJ. Identification of a gene (GPR30) with homology to the G-protein-coupled receptor superfamily associated with estrogen receptor expression in breast cancer. Genomics. 1997;45:607-17.

[46] Takada Y, Kato C, Kondo S, Korenaga R, Ando J. Cloning of cDNAs encoding G protein-coupled receptor expressed in human endothelial cells exposed to fluid shear stress. Biochem Biophys Res Commun. 1997;240:737-41.

[47] O'Dowd BF, Nguyen T, Marchese A, Cheng R, Lynch KR, Heng HH, et al. Discovery of three novel G-protein-coupled receptor genes. Genomics. 1998;47:310-3.

[48] Feng Y, Gregor P. Cloning of a novel member of the G protein-coupled receptor family related to peptide receptors. Biochem Biophys Res Commun. 1997;231:6514.

[49] Bonini JA, Anderson SM, Steiner DF. Molecular cloning and tissue expression of a novel orphan $\mathrm{G}$ protein-coupled receptor from rat lung. Biochem Biophys Res Commun. 1997;234:190-3.

[50] Kimura M, Mizukami Y, Miura T, Fujimoto K, Kobayashi S, Matsuzaki M. Orphan G protein-coupled receptor, GPR41, induces apoptosis via a p53/Bax pathway during ischemic hypoxia and reoxygenation. J Biol Chem. 2001;276:26453-60.

[51] Sawzdargo M, George SR, Nguyen T, Xu S, Kolakowski LF, O'Dowd BF. A cluster of four novel human $\mathrm{G}$ protein-coupled receptor genes occurring in close proximity to CD22 gene on chromosome 19q13.1. Biochem Biophys Res Commun. 1997;239:5437. 
[52] Filardo EJ, Quinn JA, Bland KI, Frackelton AR, Jr. Estrogen-induced activation of Erk1 and Erk-2 requires the G protein-coupled receptor homolog, GPR30, and occurs via trans-activation of the epidermal growth factor receptor through release of HBEGF. Mol Endocrinol. 2000;14:1649-60.

[53] Filardo EJ, Quinn JA, Frackelton AR, Jr., Bland KI. Estrogen action via the G proteincoupled receptor, GPR30: stimulation of adenylyl cyclase and cAMP-mediated attenuation of the epidermal growth factor receptor-to-MAPK signaling axis. Mol Endocrinol. 2002;16:70-84.

[54] Razandi M, Pedram A, Merchenthaler I, Greene GL, Levin ER. Plasma membrane estrogen receptors exist and functions as dimers. Mol Endocrinol. 2004;18:2854-65.

[55] Nadal A, Ropero AB, Laribi O, Maillet M, Fuentes E, Soria B. Nongenomic actions of estrogens and xenoestrogens by binding at a plasma membrane receptor unrelated to estrogen receptor alpha and estrogen receptor beta. Proc Natl Acad Sci U S A. 2000;97:11603-8.

[56] Revankar CM, Cimino DF, Sklar LA, Arterburn JB, Prossnitz ER. A transmembrane intracellular estrogen receptor mediates rapid cell signaling. Science. 2005;307:1625-30.

[57] Thomas P, Pang Y, Filardo EJ, Dong J. Identity of an estrogen membrane receptor coupled to a G protein in human breast cancer cells. Endocrinology. 2005;146:62432.

[58] Alexander SP, Mathie A, Peters JA. Guide to Receptors and Channels (GRAC), 3rd edition. Br J Pharmacol. 2008;153 Suppl 2:S1-S209.

[59] Prossnitz ER, Arterburn JB. International Union of Basic and Clinical Pharmacology. XCVII. G protein-coupled estrogen receptor (GPER) and its pharmacologic modulators. Pharmacol Rev. 2015;67:505-40.

[60] Sandner F, Welter H, Schwarzer JU, Kohn FM, Urbanski HF, Mayerhofer A. Expression of the oestrogen receptor GPER by testicular peritubular cells is linked to sexual maturation and male fertility. Andrology. 2014;2:695-701.

[61] Prossnitz ER, Barton M. Estrogen biology: new insights into GPER function and clinical opportunities. Mol Cell Endocrinol. 2014;389:71-83.

[62] Barton M, Prossnitz ER. Emerging roles of GPER in diabetes and atherosclerosis. Trends Endocrinol Metab. 2015;26:185-92.

[63] Wang C, Dehghani B, Magrisso IJ, Rick EA, Bonhomme E, Cody DB, et al. GPR30 contributes to estrogen-induced thymic atrophy. Mol Endocrinol. 2008;22:636-48. 
[64] Mårtensson UE, Salehi SA, Windahl S, Gomez MF, Sward K, Daszkiewicz-Nilsson J, et al. Deletion of the $\mathrm{G}$ protein-coupled receptor 30 impairs glucose tolerance, reduces bone growth, increases blood pressure, and eliminates estradiol-stimulated insulin release in female mice. Endocrinology. 2009;150:687-98.

[65] Haas E, Bhattacharya I, Brailoiu E, Damjanovic M, Brailoiu GC, Gao X, et al. Regulatory role of $\mathrm{G}$ protein-coupled estrogen receptor for vascular function and obesity. Circ Res. 2009;104:288-91.

[66] Ford J, Hajibeigi A, Long M, Hahner L, Gore C, Hsieh JT, et al. GPR30 deficiency causes increased bone mass, mineralization, and growth plate proliferative activity in male mice. J Bone Miner Res. 2011;26:298-307.

[67] Delbeck M, Golz S, Vonk R, Janssen W, Hucho T, Isensee J, et al. Impaired leftventricular cardiac function in male GPR30-deficient mice. Mol Med Rep. 2011;4:3740 .

[68] Meyer MR, Fredette NC, Howard T, Hu C, Ramesh C, Daniel C, et al. G protein-coupled estrogen receptor protects from atherosclerosis. Sci Rep. 2014;4:7564.

[69] Meyer MR, Amann K, Field AS, Hu C, Hathaway HJ, Kanagy NL, et al. Deletion of G protein-coupled estrogen receptor increases endothelial vasoconstriction. Hypertension. 2012;59:507-12.

[70] Sharma G, Prossnitz ER. Mechanisms of estradiol-induced insulin secretion by the G protein-coupled estrogen receptor GPR30/GPER in pancreatic beta-cells. Endocrinology. 2011;152:3030-9.

[71] Wang Y, Wu Z, Thorin E, Tremblay J, Lavoie JL, Luo H, et al. Estrogen and testosterone in concert with EFNB3 regulate vascular smooth muscle cell contractility and blood pressure. Am J Physiol Heart Circ Physiol. 2016:ajpheart 008732015.

[72] Maximov PY, Lee TM, Jordan VC. The discovery and development of selective estrogen receptor modulators (SERMs) for clinical practice. Curr Clin Pharmacol. 2013;8:135-55.

[73] Hussain Y, Ding Q, Connelly PW, Brunt JH, Ban MR, McIntyre AD, et al. G-protein estrogen receptor as a regulator of low-density lipoprotein cholesterol metabolism: cellular and population genetic studies. Arterioscler Thromb Vasc Biol. 2015;35:213-21.

[74] Chourasia TK, Pang Y, Thomas P. The catecholestrogen, 2-hydroxyestradiol-17beta, acts as a $\mathrm{G}$ protein-coupled estrogen receptor 1 (GPER/GPR30) antagonist to promote the resumption of meiosis in zebrafish oocytes. Biol Reprod. 2015. 
[75] Lindsey SH. Importance of estrogen metabolites. Hypertension. 2014;64:21-2.

[76] Santolla MF, De Francesco EM, Lappano R, Rosano C, Abonante S, Maggiolini M. Niacin activates the $G$ protein estrogen receptor (GPER)-mediated signalling. Cell Signal. 2014;26:1466-75.

[77] Rowlands DJ, Chapple S, Siow RC, Mann GE. Equol-stimulated mitochondrial reactive oxygen species activate endothelial nitric oxide synthase and redox signaling in endothelial cells: roles for F-actin and GPR30. Hypertension. 2011;57:833-40.

[78] Moreno-Ulloa A, Mendez-Luna D, Beltran-Partida E, Castillo C, Guevara G, RamirezSanchez I, et al. The effects of (-)-epicatechin on endothelial cells involve the $\mathrm{G}$ protein-coupled estrogen receptor (GPER). Pharmacol Res. 2015;100:309-20.

[79] Petrie WK, Dennis MK, Hu C, Dai D, Arterburn JB, Smith HO, et al. G protein-coupled estrogen receptor-selective ligands modulate endometrial tumor growth. Obstet Gynecol Int. 2013;2013:472720.

[80] Vivacqua A, Lappano R, De Marco P, Sisci D, Aquila S, De Amicis F, et al. G proteincoupled receptor 30 expression is up-regulated by EGF and TGF alpha in estrogen receptor alpha-positive cancer cells. Mol Endocrinol. 2009;23:1815-26.

[81] Caroccia B, Seccia TM, Campos AG, Gioco F, Kuppusamy M, Ceolotto G, et al. GPER-1 and estrogen receptor-beta ligands modulate aldosterone synthesis. Endocrinology. 2014;155:4296-304.

[82] Nikolic I, Liu D, Bell JA, Collins J, Steenbergen C, Murphy E. Treatment with an estrogen receptor-beta-selective agonist is cardioprotective. J Mol Cell Cardiol. 2007;42:769-80.

[83] Traupe T, Stettler CD, Li H, Haas E, Bhattacharya I, Minotti R, et al. Distinct roles of estrogen receptors alpha and beta mediating acute vasodilation of epicardial coronary arteries. Hypertension. 2007;49:1364-70.

[84] Pedram A, Razandi M, Korach KS, Narayanan R, Dalton JT, Levin ER. ERbeta selective agonist inhibits angiotensin-induced cardiovascular pathology in female mice. Endocrinology. 2013;154:4352-64.

[85] Stauffer SR, Coletta CJ, Tedesco R, Nishiguchi G, Carlson K, Sun J, et al. Pyrazole ligands: structure-affinity/activity relationships and estrogen receptor-alphaselective agonists. J Med Chem. 2000;43:4934-47.

[86] Menazza S, Murphy E. The expanding complexity of estrogen receptor signaling in the cardiovascular system. Circ Res. 2016:published online January 7, 2016. 
[87] Tiano JP, Delghingaro-Augusto V, Le May C, Liu S, Kaw MK, Khuder SS, et al. Estrogen receptor activation reduces lipid synthesis in pancreatic islets and prevents beta cell failure in rodent models of type 2 diabetes. J Clin Invest. 2011;121:3331-42.

[88] Barton M, Meyer MR. Nicolaus Copernicus and the rapid vascular responses to aldosterone. Trends Endocrinol Metab. 2015;26:396-8.

[89] Wendler A, Albrecht C, Wehling M. Nongenomic actions of aldosterone and progesterone revisited. Steroids. 2012;77:1002-6.

[90] Gros R, Ding Q, Sklar LA, Prossnitz EE, Arterburn JB, Chorazyczewski J, et al. GPR30 expression is required for the mineralocorticoid receptor-independent rapid vascular effects of aldosterone. Hypertension. 2011;57:442-51.

[91] Gros R, Ding Q, Liu B, Chorazyczewski J, Feldman RD. Aldosterone mediates its rapid effects in vascular endothelial cells through GPER activation. Am J Physiol Cell Physiol. 2013;304:C532-40.

[92] Cheng SB, Dong J, Pang Y, LaRocca J, Hixon M, Thomas P, et al. Anatomical location and redistribution of $G$ protein-coupled estrogen receptor-1 during the estrus cycle in mouse kidney and specific binding to estrogens but not aldosterone. Mol Cell Endocrinol. 2014;382:950-9.

[93] Rigiracciolo DC, Scarpelli A, Lappano R, Pisano A, Santolla MF, Avino S, et al. GPER is involved in the stimulatory effects of aldosterone in breast cancer cells and breast tumor-derived endothelial cells. Oncotarget. 2015.

[94] Gerhard M, Ganz P. How do we explain the clinical benefits of estrogen? From bedside to bench. Circulation. 1995;92:5-8.

[95] Hodgin JB, Krege JH, Reddick RL, Korach KS, Smithies O, Maeda N. Estrogen receptor alpha is a major mediator of 17 beta-estradiol's atheroprotective effects on lesion size in Apoe-/- mice. J Clin Invest. 2001;107:333-40.

[96] Villablanca AC, Tenwolde A, Lee M, Huck M, Mumenthaler S, Rutledge JC. 17betaestradiol prevents early-stage atherosclerosis in estrogen receptor-alpha deficient female mice. J Cardiovasc Transl Res. 2009;2:289-99.

[97] Sharma G, Hu C, Brigman JL, Zhu G, Hathaway HJ, Prossnitz ER. GPER deficiency in male mice results in insulin resistance, dyslipidemia, and a proinflammatory state. Endocrinology. 2013;154:4136-45.

[98] Jessup JA, Lindsey SH, Wang H, Chappell MC, Groban L. Attenuation of salt-induced cardiac remodeling and diastolic dysfunction by the GPER agonist G-1 in female mRen2.Lewis rats. PLoS One. 2010;5:e15433. 
[99] Lindsey SH, Yamaleyeva LM, Brosnihan KB, Gallagher PE, Chappell MC. Estrogen receptor GPR30 reduces oxidative stress and proteinuria in the salt-sensitive female mRen2.Lewis rat. Hypertension. 2011;58:665-71.

[100] Zhu P, Yuen JM, Sham KW, Cheng CH. GPER mediates the inhibitory actions of estrogen on adipogenesis in 3T3-L1 cells through perturbation of mitotic clonal expansion. Gen Comp Endocrinol. 2013;193:19-26.

[101] Borradaile NM, de Dreu LE, Wilcox LJ, Edwards JY, Huff MW. Soya phytoestrogens, genistein and daidzein, decrease apolipoprotein B secretion from HepG2 cells through multiple mechanisms. Biochem J. 2002;366:531-9.

[102] Villa P, Costantini B, Suriano R, Perri C, Macri F, Ricciardi L, et al. The differential effect of the phytoestrogen genistein on cardiovascular risk factors in postmenopausal women: relationship with the metabolic status. J Clin Endocrinol Metab. 2009;94:552-8.

[103] Clifton-Bligh PB, Baber RJ, Fulcher GR, Nery ML, Moreton T. The effect of isoflavones extracted from red clover (Rimostil) on lipid and bone metabolism. Menopause. 2001;8:259-65.

[104] Lemieux C, Phaneuf D, Labrie F, Giguere V, Richard D, Deshaies Y. Estrogen receptor alpha-mediated adiposity-lowering and hypocholesterolemic actions of the selective estrogen receptor modulator acolbifene. Int J Obes (Lond). 2005;29:1236-44.

[105] Balhuizen A, Kumar R, Amisten S, Lundquist I, Salehi A. Activation of G proteincoupled receptor 30 modulates hormone secretion and counteracts cytokineinduced apoptosis in pancreatic islets of female mice. Mol Cell Endocrinol. 2010;320:16-24.

[106] Savolainen-Peltonen H, Luoto NM, Kangas L, Hayry P. Selective estrogen receptor modulators prevent neointima formation after vascular injury. Mol Cell Endocrinol. 2004;227:9-20.

[107] Lafferty AR, Torpy DJ, Stowasser M, Taymans SE, Lin JP, Huggard P, et al. A novel genetic locus for low renin hypertension: familial hyperaldosteronism type II maps to chromosome 7 (7p22). J Med Genet. 2000;37:831-5.

[108] Feldman RD, Gros R, Ding Q, Hussain Y, Ban MR, McIntyre AD, et al. A common hypofunctional genetic variant of GPER is associated with increased blood pressure in women. Br J Clin Pharmacol. 2014;78:1441-52.

[109] Meyer MR, Baretella O, Prossnitz ER, Barton M. Dilation of epicardial coronary arteries by the G protein-coupled estrogen receptor agonists G-1 and ICI 182,780. Pharmacology. 2010;86:58-64. 
[110] Leung HS, Yung LM, Leung FP, Yao X, Chen ZY, Ko WH, et al. Tamoxifen dilates porcine coronary arteries: roles for nitric oxide and ouabain-sensitive mechanisms. Br J Pharmacol. 2006;149:703-11.

[111] Tatchum-Talom R, Martel C, Labrie F, Marette A. Acute vascular effects of the selective estrogen receptor modulator EM-652 (SCH 57068) in the rat mesenteric vascular bed. Cardiovasc Res. 2003;57:535-43.

[112] Figtree GA, Webb CM, Collins P. Tamoxifen acutely relaxes coronary arteries by an endothelium-, nitric oxide-, and estrogen receptor-dependent mechanism. J Pharmacol Exp Ther. 2000;295:519-23.

[113] Chan YC, Leung FP, Yao X, Lau CW, Vanhoutte PM, Huang Y. Raloxifene relaxes rat pulmonary arteries and veins: roles of gender, endothelium, and antagonism of Ca2+ influx. J Pharmacol Exp Ther. 2005;312:1266-71.

[114] Figtree GA, Lu Y, Webb CM, Collins P. Raloxifene acutely relaxes rabbit coronary arteries in vitro by an estrogen receptor-dependent and nitric oxide-dependent mechanism. Circulation. 1999;100:1095-101.

[115] Simoncini T, Genazzani AR, Liao JK. Nongenomic mechanisms of endothelial nitric oxide synthase activation by the selective estrogen receptor modulator raloxifene. Circulation. 2002;105:1368-73.

[116] Sarrel PM, Nawaz H, Chan W, Fuchs M, Katz DL. Raloxifene and endothelial function in healthy postmenopausal women. Am J Obstet Gynecol. 2003;188:304-9.

[117] Sumino H, Ichikawa S, Kasama S, Takahashi T, Sakamoto H, Koizumi A, et al. Effects of raloxifene on brachial arterial endothelial function, carotid wall thickness, and arterial stiffness in osteoporotic postmenopausal women. Int Heart J. 2010;51:60-7.

[118] Saitta A, Altavilla D, Cucinotta D, Morabito N, Frisina N, Corrado F, et al. Randomized, double-blind, placebo-controlled study on effects of raloxifene and hormone replacement therapy on plasma no concentrations, endothelin-1 levels, and endothelium-dependent vasodilation in postmenopausal women. Arterioscler Thromb Vasc Biol. 2001;21:1512-9.

[119] Obayashi S, Terauchi M, Kato K, Akiyoshi M, Kubota T. Raloxifene temporarily reduces arterial stiffness. J Obstet Gynaecol Res. 2010;36:1229-35.

[120] da Costa LS, de Oliveira MA, Rubim VS, Wajngarten M, Aldrighi JM, Rosano GM, et al. Effects of hormone replacement therapy or raloxifene on ambulatory blood pressure and arterial stiffness in treated hypertensive postmenopausal women. Am J Cardiol. 2004;94:1453-6. 
[121] Vergote I, Abram P. Fulvestrant, a new treatment option for advanced breast cancer: tolerability versus existing agents. Ann Oncol. 2006;17:200-4.

[122] de Valk-de Roo GW, Stehouwer CD, Meijer P, Mijatovic V, Kluft C, Kenemans P, et al. Both raloxifene and estrogen reduce major cardiovascular risk factors in healthy postmenopausal women: A 2-year, placebo-controlled study. Arterioscler Thromb Vasc Biol. 1999;19:2993-3000.

[123] De Leo V, la Marca A, Morgante G, Lanzetta D, Setacci C, Petraglia F. Randomized control study of the effects of raloxifene on serum lipids and homocysteine in older women. Am J Obstet Gynecol. 2001;184:350-3.

[124] Downs RW, Jr., Moffett AM, Ghosh A, Cox DA, Dowsett SA, Harper K. Effects of arzoxifene on bone, lipid markers, and safety parameters in postmenopausal women with low bone mass. Osteoporos Int. 2010;21:1215-26.

[125] Yoshii T, Yamada M, Minami T, Tsunoda T, Sasaki M, Kondo Y, et al. The effects of bazedoxifene on bone, glucose, and lipid metabolism in postmenopausal women with type 2 diabetes: an exploratory pilot study. J Clin Med Res. 2015;7:762-9.

[126] Komi J, Lankinen KS, Harkonen P, DeGregorio MW, Voipio S, Kivinen S, et al. Effects of ospemifene and raloxifene on hormonal status, lipids, genital tract, and tolerability in postmenopausal women. Menopause. 2005;12:202-9.

[127] Ylikorkala O, Cacciatore B, Halonen K, Lassila R, Lammintausta R, Rutanen EM, et al. Effects of ospemifene, a novel SERM, on vascular markers and function in healthy, postmenopausal women. Menopause. 2003;10:440-7.

[128] Collins P, Mosca L, Geiger MJ, Grady D, Kornitzer M, Amewou-Atisso MG, et al. Effects of the selective estrogen receptor modulator raloxifene on coronary outcomes in The Raloxifene Use for the Heart Trial. Results of subgroup analyses by age and other factors. Circulation. 2009;119:922-30.

[129] Ensrud K, LaCroix A, Thompson JR, Thompson DD, Eastell R, Reid DM, et al. Lasofoxifene and cardiovascular events in postmenopausal women with osteoporosis: Five-year results from the Postmenopausal Evaluation and Risk Reduction with Lasofoxifene (PEARL) trial. Circulation. 2010;122:1716-24.

[130] Guo X, Razandi M, Pedram A, Kassab G, Levin ER. Estrogen induces vascular wall dilation: mediation through kinase signaling to nitric oxide and estrogen receptors alpha and beta. J Biol Chem. 2005;280:19704-10.

[131] Tunaru S, Kero J, Schaub A, Wufka C, Blaukat A, Pfeffer K, et al. PUMA-G and HM74 are receptors for nicotinic acid and mediate its anti-lipolytic effect. Nat Med. 2003;9:352-5. 
[132] Soga T, Kamohara M, Takasaki J, Matsumoto S, Saito T, Ohishi T, et al. Molecular identification of nicotinic acid receptor. Biochem Biophys Res Commun. 2003;303:364-9.

[133] Wise A, Foord SM, Fraser NJ, Barnes AA, Elshourbagy N, Eilert M, et al. Molecular identification of high and low affinity receptors for nicotinic acid. J Biol Chem. 2003;278:9869-74.

[134] Itzhaki O, Greenberg E, Shalmon B, Kubi A, Treves AJ, Shapira-Frommer R, et al. Nicotinamide inhibits vasculogenic mimicry, an alternative vascularization pathway observed in highly aggressive melanoma. PLoS One. 2013;8:e57160.

[135] Pelekanou V, Kampa M, Kiagiadaki F, Deli A, Theodoropoulos P, Agrogiannis G, et al. Estrogen anti-inflammatory activity on human monocytes is mediated through cross-talk between estrogen receptor ERalpha36 and GPR30/GPER1. J Leukoc Biol. 2015.

[136] Tamaki M, Konno Y, Kobayashi Y, Takeda M, Itoga M, Moritoki Y, et al. Expression and functional roles of G-protein-coupled estrogen receptor (GPER) in human eosinophils. Immunol Lett. 2014;160:72-8.

[137] Brunsing RL, Owens KS, Prossnitz ER. The G protein-coupled estrogen receptor (GPER) agonist G-1 expands the regulatory T-cell population under TH17-polarizing conditions. J Immunother. 2013;36:190-6.

[138] Brunsing RL, Prossnitz ER. Induction of interleukin-10 in the T helper type 17 effector population by the G protein coupled estrogen receptor (GPER) agonist G-1. Immunology. 2011;134:93-106.

[139] Catusse J, Wollner S, Leick M, Schrottner P, Schraufstatter I, Burger M. Attenuation of CXCR4 responses by CCL18 in acute lymphocytic leukemia B cells. J Cell Physiol. 2010;225:792-800.

[140] Cabas I, Rodenas MC, Abellan E, Meseguer J, Mulero V, Garcia-Ayala A. Estrogen signaling through the $\mathrm{G}$ protein-coupled estrogen receptor regulates granulocyte activation in fish. J Immunol. 2013;191:4628-39.

[141] Chakrabarti S, Davidge ST. G-protein coupled receptor 30 (GPR30): a novel regulator of endothelial inflammation. PLoS One. 2012;7:e52357.

[142] Meyer MR, Fredette NC, Barton M, Prossnitz ER. G protein-coupled estrogen receptor inhibits vascular prostanoid production and activity. J Endocrinol. 2015;227:61-9. 
[143] Zhao Z, Wang H, Lin M, Groban L. GPR30 decreases cardiac chymase/angiotensin II by inhibiting local mast cell number. Biochem Biophys Res Commun. 2015;459:1316.

[144] Blasko E, Haskell CA, Leung S, Gualtieri G, Halks-Miller M, Mahmoudi M, et al. Beneficial role of the GPR30 agonist G-1 in an animal model of multiple sclerosis. J Neuroimmunol. 2009;214:67-77.

[145] Wang C, Dehghani B, Li Y, Kaler LJ, Proctor T, Vandenbark AA, et al. Membrane estrogen receptor regulates experimental autoimmune encephalomyelitis through up-regulation of programmed death 1. J Immunol. 2009;182:3294-303.

[146] Yates MA, Li Y, Chlebeck PJ, Offner H. GPR30, but not estrogen receptor-alpha, is crucial in the treatment of experimental autoimmune encephalomyelitis by oral ethinyl estradiol. BMC Immunol. 2010;11:20.

[147] Ulitzky L, Lafer MM, KuKuruga MA, Silberstein E, Cehan N, Taylor DR. A New Signaling Pathway for HCV Inhibition by Estrogen: GPR30 Activation Leads to Cleavage of Occludin by MMP-9. PLoS One. 2016;11:e0145212.

[148] Fujimura T, Takahashi S, Kume H, Urano T, Takayama K, Yamada Y, et al. Toremifene, a selective estrogen receptor modulator, significantly improved biochemical recurrence in bone metastatic prostate cancer: a randomized controlled phase II a trial. BMC Cancer. 2015;15:836.

[149] Khan S, Ebeling MC, Chauhan N, Thompson PA, Gara RK, Ganju A, et al. Ormeloxifene suppresses desmoplasia and enhances sensitivity of gemcitabine in pancreatic cancer. Cancer Res. 2015;75:2292-304.

[150] De Cremer K, Delattin N, De Brucker K, Peeters A, Kucharikova S, Gerits E, et al. Oral administration of the broad-spectrum antibiofilm compound toremifene inhibits Candida albicans and Staphylococcus aureus biofilm formation in vivo. Antimicrob Agents Chemother. 2014;58:7606-10.

[151] Yuan S. Possible FDA-approved drugs to treat Ebola virus infection. Infect Dis Poverty. 2015;4:23.

[152] Elangovan S, Pathania R, Ramachandran S, Ananth S, Padia RN, Lan L, et al. The niacin/butyrate receptor GPR109A suppresses mammary tumorigenesis by inhibiting cell survival. Cancer Res. 2014;74:1166-78.

[153] Mineva ND, Paulson KE, Naber SP, Yee AS, Sonenshein GE. Epigallocatechin-3-gallate inhibits stem-like inflammatory breast cancer cells. PLoS One. 2013;8:e73464. 
[154] Arevalo MA, Diz-Chaves Y, Santos-Galindo M, Bellini MJ, Garcia-Segura LM. Selective oestrogen receptor modulators decrease the inflammatory response of glial cells. J Neuroendocrinol. 2012;24:183-90.

[155] Esposito E, Iacono A, Raso GM, Pacilio M, Coppola A, Di Carlo R, et al. Raloxifene, a selective estrogen receptor modulator, reduces carrageenan-induced acute inflammation in normal and ovariectomized rats. Endocrinology. 2005;146:3301-8.

[156] Ji G, Zhang Y, Yang Q, Cheng S, Hao J, Zhao X, et al. Genistein suppresses LPS-induced inflammatory response through inhibiting NF-kappaB following AMP kinase activation in RAW 264.7 macrophages. PLoS One. 2012;7:e53101.

[157] Jia Z, Babu PV, Si H, Nallasamy P, Zhu H, Zhen W, et al. Genistein inhibits TNF-alphainduced endothelial inflammation through the protein kinase pathway A and improves vascular inflammation in C57BL/6 mice. Int J Cardiol. 2013;168:2637-45.

[158] Khan AQ, Khan R, Rehman MU, Lateef A, Tahir M, Ali F, et al. Soy isoflavones (daidzein \& genistein) inhibit 12-0-tetradecanoylphorbol-13-acetate (TPA)-induced cutaneous inflammation via modulation of COX-2 and NF-kappaB in Swiss albino mice. Toxicology. 2012;302:266-74.

[159] Babu PV, Si H, Fu Z, Zhen W, Liu D. Genistein prevents hyperglycemia-induced monocyte adhesion to human aortic endothelial cells through preservation of the cAMP signaling pathway and ameliorates vascular inflammation in obese diabetic mice. J Nutr. 2012;142:724-30.

[160] Wu BJ, Chen K, Barter PJ, Rye KA. Niacin inhibits vascular inflammation via the induction of heme oxygenase-1. Circulation. 2012;125:150-8.

[161] Kalhan R, Smith LJ, Nlend MC, Nair A, Hixon JL, Sporn PH. A mechanism of benefit of soy genistein in asthma: inhibition of eosinophil p38-dependent leukotriene synthesis. Clin Exp Allergy. 2008;38:103-12.

[162] Perez B, Henriquez C, Sarmiento J, Morales N, Folch H, Galesio JS, et al. Tamoxifen as a new therapeutic tool for neutrophilic lung inflammation. Respirology. 2016;21:112-8.

[163] Yadav R, Liu Y, Kwok S, Hama S, France M, Eatough R, et al. Effect of extendedrelease niacin on high-density lipoprotein (HDL) functionality, lipoprotein metabolism, and mediators of vascular inflammation in statin-treated patients. J Am Heart Assoc. 2015;4:e001508.

[164] Schug TT, Janesick A, Blumberg B, Heindel JJ. Endocrine disrupting chemicals and disease susceptibility. J Steroid Biochem Mol Biol. 2011;127:204-15. 
[165] Schiliro T, Gorrasi I, Longo A, Coluccia S, Gilli G. Endocrine disrupting activity in fruits and vegetables evaluated with the E-screen assay in relation to pesticide residues. J Steroid Biochem Mol Biol. 2011;127:139-46.

[166] Wagner M, Oehlmann J. Endocrine disruptors in bottled mineral water: estrogenic activity in the E-Screen. J Steroid Biochem Mol Biol. 2011;127:128-35.

[167] Zinedine A, Soriano JM, Molto JC, Manes J. Review on the toxicity, occurrence, metabolism, detoxification, regulations and intake of zearalenone: an oestrogenic mycotoxin. Food Chem Toxicol. 2007;45:1-18.

[168] Rubin BS. Bisphenol A: an endocrine disruptor with widespread exposure and multiple effects. J Steroid Biochem Mol Biol. 2011;127:27-34.

[169] Vandenberg LN, Hauser R, Marcus M, Olea N, Welshons WV. Human exposure to bisphenol A (BPA). Reprod Toxicol. 2007;24:139-77.

[170] Mendonca K, Hauser R, Calafat AM, Arbuckle TE, Duty SM. Bisphenol A concentrations in maternal breast milk and infant urine. Int Arch Occup Environ Health. 2014;87:13-20.

[171] Campesi I, Capobianco G, Dessole S, Occhioni S, Montella A, Franconi F. Estrogenic compounds have divergent effects on human endothelial progenitor cell migration according to sex of the donor. J Vasc Res. 2016;52:273-8.

[172] Chevalier N, Bouskine A, Fenichel P. Bisphenol A promotes testicular seminoma cell proliferation through GPER/GPR30. Int J Cancer. 2012;130:241-2.

[173] Chevalier N, Fenichel P. Bisphenol A: Targeting metabolic tissues. Rev Endocr Metab Disord. 2016.

[174] Ahmadkhaniha R, Mansouri M, Yunesian M, Omidfar K, Jeddi MZ, Larijani B, et al. Association of urinary bisphenol a concentration with type-2 diabetes mellitus. J Environ Health Sci Eng. 2014;12:64.

[175] Kim JH, Rozek LS, Soliman AS, Sartor MA, Hablas A, Seifeldin IA, et al. Bisphenol Aassociated epigenomic changes in prepubescent girls: a cross-sectional study in Gharbiah, Egypt. Environ Health. 2013;12:33.

[176] Trasande L, Attina TM. Association of exposure to di-2-ethylhexylphthalate replacements with increased blood pressure in children and adolescents. Hypertension. 2015;66:301-8.

[177] Akin L, Kendirci M, Narin F, Kurtoglu S, Saraymen R, Kondolot M, et al. The endocrine disruptor bisphenol A may play a role in the aetiopathogenesis of polycystic ovary syndrome in adolescent girls. Acta Paediatr. 2015;104:e171-7. 
[178] Kandaraki E, Chatzigeorgiou A, Livadas S, Palioura E, Economou F, Koutsilieris M, et al. Endocrine disruptors and polycystic ovary syndrome (PCOS): elevated serum levels of bisphenol A in women with PCOS. J Clin Endocrinol Metab. 2011;96:E480-4.

[179] Palioura E, Diamanti-Kandarakis E. Polycystic ovary syndrome (PCOS) and endocrine disrupting chemicals (EDCs). Rev Endocr Metab Disord. 2016.

[180] Rubin BS, Soto AM. Bisphenol A: Perinatal exposure and body weight. Mol Cell Endocrinol. 2009;304:55-62.

[181] Locher R, Emmanuele L, Suter PM, Vetter W, Barton M. Green tea polyphenols inhibit human vascular smooth muscle cell proliferation stimulated by native lowdensity lipoprotein. Eur J Pharmacol. 2002;434:1-7.

[182] Zarrabeitia R, Ojeda-Fernandez L, Recio L, Bernabeu C, Parra JA, Albinana V, et al. Bazedoxifene, a new orphan drug for the treatment of bleeding in hereditary haemorrhagic telangiectasia. Thromb Haemost. 2016;115.

[183] Zhang W, Yang F, Luo J, Chen F, Gu J, Guan X. A novel GPR30 rs10235056 A>G polymorphism associated with post-transcriptional regulation in lymphoblastoid cell lines. Biomarkers. 2014;19:417-23.

[184] Chevalier N, Paul-Bellon R, Camparo P, Michiels JF, Chevallier D, Fenichel P. Genetic variants of GPER/GPR30, a novel estrogen-related G protein receptor, are associated with human seminoma. Int J Mol Sci. 2014;15:1574-89.

[185] Kakinuma N, Sato M, Yamada T, Kohu K, Nakajima M, Akiyama T, et al. Cloning of novel LERGU mRNAs in GPR30 3' untranslated region and detection of $2 \mathrm{bp}$-deletion polymorphism in gastric cancer. Cancer Sci. 2005;96:191-6.

[186] Giess M, Lattrich C, Springwald A, Goerse R, Ortmann O, Treeck O. GPR30 gene polymorphisms are associated with progesterone receptor status and histopathological characteristics of breast cancer patients. J Steroid Biochem Mol Biol. 2010;118:7-12.

[187] Kasap B, Ozturk Turhan N, Edgunlu T, Duran M, Akbaba E, Oner G. G-proteincoupled estrogen receptor-30 gene polymorphisms are associated with uterine leiomyoma risk. Bosn J Basic Med Sci. 2016.

[188] Korkmaz HA, Edgunlu T, Eren E, Demir K, Cakir ED, Celik SK, et al. GPR30 gene polymorphisms are associated with gynecomastia risk in adolescents. Horm Res Paediatr. 2015;83:177-82. 


\section{Figure Legend}

Activators (left, green) and inhibitors (right, red) of G protein-coupled estrogen receptor (GPER) signaling. GPER is activated by natural estrogens (endogenous estrogen such as $17 \beta$-estradiol ( $\left.\mathrm{E}_{2}\right)$ or 2-methoxyestradiol) as well as by phytoestrogens (such quercetin, genistein, epicatechin, resveratrol), highly stable environmental pollutants ("endocrine disruptors") also known as xenoestrogens [including atrazine, bisphenol A, nonylphenol, and p,p0-dichlorodiphenyltrichloroethane (DDT)]. Although zearalonone is plant (fungus)-derived and thus by definition a phytoestrogen as shown in the figure, due to its toxicity as a environmental mycotoxin is also considered a xenoestrogen. Similarly, daidzein - which like genistein is a soy-derived phytoestrogen - is also considered an environmental xenoestrogen REF. Equol is a metabolite of daidzein and thus must be considered of phytoestrogen-derivative rather than of plant origin REF. Importantly, GPER is also activated by niacin (vitamin $B_{3}$ ), selective estrogen receptor (ER) modulators (SERMs), and selective ER downregulators (SERDs). The latter two exhibit inhibitory activity on the "classical" estrogen receptors, ER $\alpha$ and ER $\beta$. GPER is also activated by selective synthetic, non-steroidal, small molecule compounds, such as G-1. Inhibition of GPER can be achieved utilizing synthetic GPER-selective small molecule compounds G15 and G36, and the non ER-selective compound ethyl 3-[5-(2ethoxycarbonyl-1-methylvinyloxy)-1-methyl-1H- indol-3-yl]but-2-enoate (MIBE). The catechol estrogen metabolite 2-hydroxy-17 $\beta$--estradiol (2-OH-E2) and the 16-OHDHEAS metabolite estriol $\left(E_{3}\right)$ also act as GPER antagonists. Figure reproduced from Trends Endocrinol Metabol 2015; 26: 185-192, with the permission of Cell Press. 
Figure 1

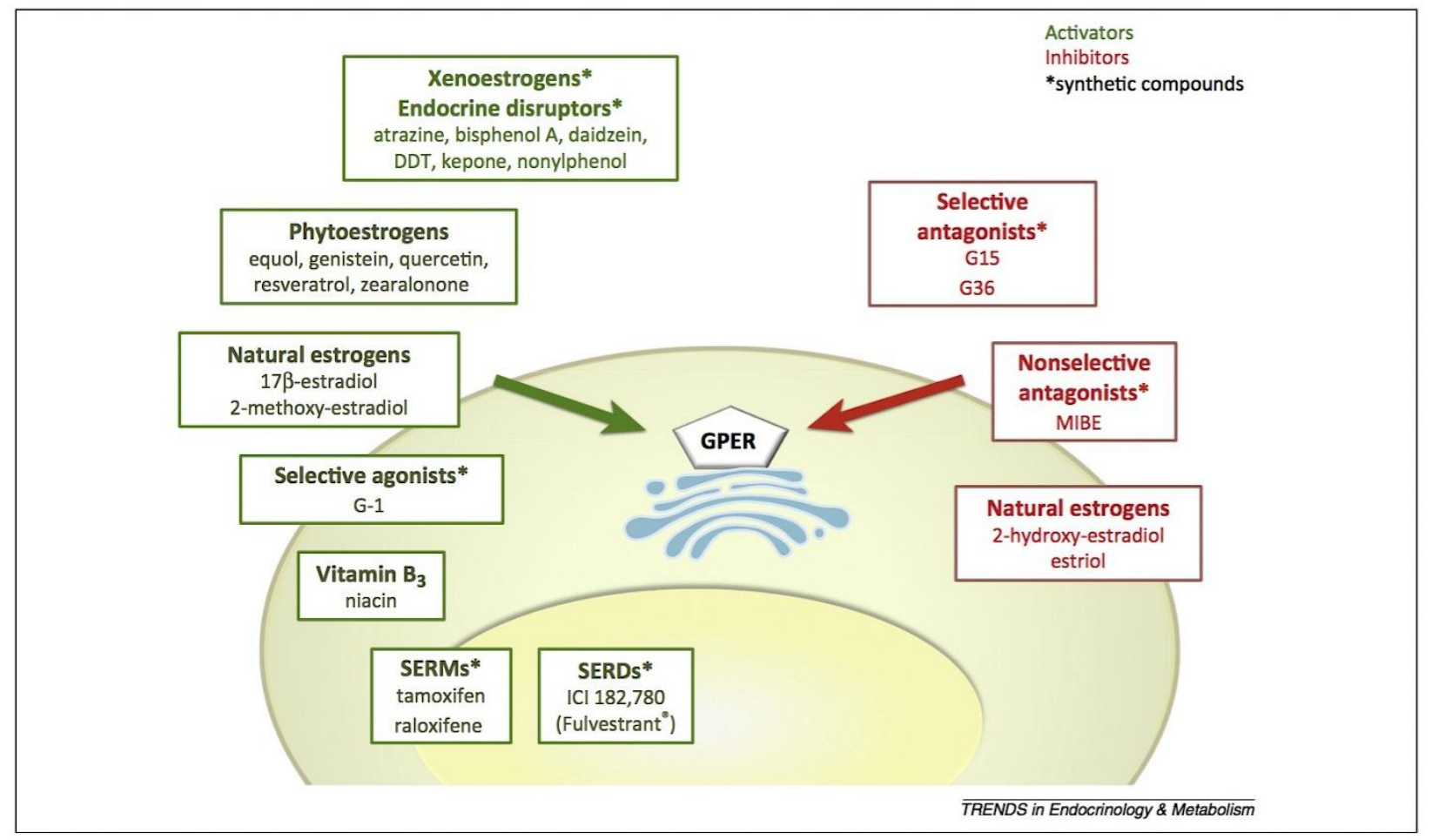


Graphical Abstract

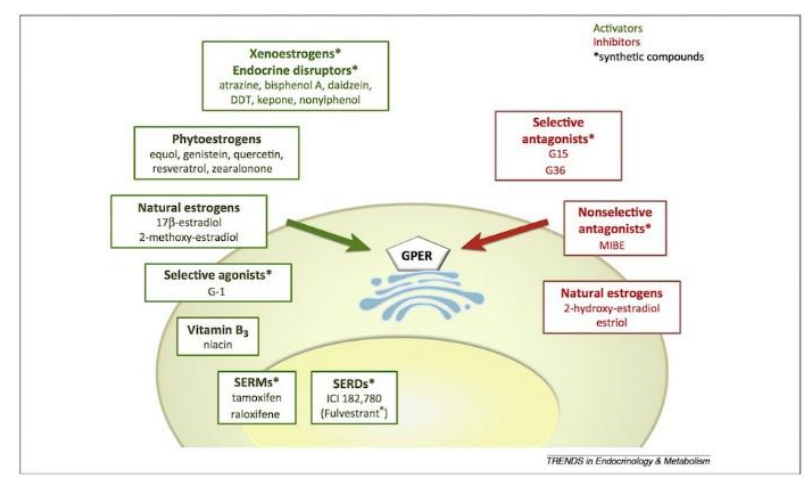

